\title{
Microstructures and Hydrogen Permeability of Nb-Ti-Ni Alloys with High Resistance to Hydrogen Embrittlement
}

\author{
Kunihiko Hashi*1, Kazuhiro Ishikawa, Takeshi Matsuda and Kiyoshi Aoki*2 \\ Department of Materials Science, Kitami Institute of Technology, Kitami 090-8507, Japan
}

Microstructures and hydrogen permeability $(\Phi)$ of as-cast Nb-Ti-Ni alloys have been investigated by scanning electron microscopy (SEM) and by the gas permeation technique, respectively. The $\Phi$ value increases with increasing temperature and the amount of the Nb content for every alloy. In these alloys, the $\mathrm{Nb}_{39} \mathrm{Ti}_{31} \mathrm{Ni}_{30}$ alloy, consisting of the primary bcc- $(\mathrm{Nb}, \mathrm{Ti})$ solid solution and the eutectic $\{(\mathrm{Nb}, \mathrm{Ti})+\mathrm{TiNi}\}$ phase, shows the highest $\Phi$, which is equivalent to that of Pd. On the other hand, the $\mathrm{Nb}_{10} \mathrm{Ti}_{50} \mathrm{Ni}_{40}$ alloy, consisting of the primary B2-TiNi compound and the eutectic $\{(\mathrm{Nb}, \mathrm{Ti})+\mathrm{TiNi}\}$ phase, shows the lowest $\Phi$ value among the alloys for which $\Phi$ is measurable. Eutectic microstructures suppress the hydrogen embrittlement, while the primary $(\mathrm{Nb}, \mathrm{Ti})$ phase contributes to the hydrogen permeation in these alloys. The present work demonstrates that duplex alloys containing eutectic microstructures are promising for hydrogen permeation membranes with high resistance to the hydrogen embrittlement.

(Received December 27, 2004; Accepted March 14, 2005; Published May 15, 2005)

Keywords: hydrogen permeation, hydrogen embrittlement, TiNi intermetallic, eutectic structure

\section{Introduction}

Gaseous hydrogen produced by chemical processes such as steam reforming of hydrocarbons contains much $\mathrm{CO}$ gas which damages the Pt electrode of fuel cells, so that such hydrogen gas must be purified using the hydrogen permeation alloy membrane and so on. ${ }^{1)} \mathrm{Pd}-\mathrm{Ag}$ alloys are used commercially as the hydrogen permeation membrane to produce high purity hydrogen (99.99999 mass\% or more), ${ }^{2)}$ but they are too expensive and scarce in resources. Then, it is strongly desired the development of low cost and high performance hydrogen permeation alloy membranes. ${ }^{3)}$ In order to develop high-performance membranes, we first examine hydrogen permeation flux, $J$, through the membrane. $J$ is described on the basis of the Fick's first law of the steady state diffusion and the Sieverts' law as follows.

$$
J=D K \Delta P^{1 / 2} / L=\Phi \Delta P^{1 / 2} / L
$$

Here, $D$ and $K$ are the hydrogen diffusion coefficient and the hydrogen solubility coefficient, respectively, and the product of them is hydrogen permeability. $\Phi \Delta P^{1 / 2}$ and $L$ are the difference of square root of the hydrogen pressure at both sides of the membrane and the thickness of the membrane, respectively. The usual method to attain large $J$ is to search for high $\Phi$ alloys. $\Phi$ of $5 \mathrm{~A}$ metals such as $\mathrm{V}, \mathrm{Nb}$ and Ta are higher than that of $\mathrm{Pd}$ and $\mathrm{Pd}-\mathrm{Ag}$ alloys, ${ }^{4)}$ so that they are promising for hydrogen permeation membranes. ${ }^{5-8)}$ However, they suffer from the severe hydrogen embrittlement, because high $\Phi$ requires large $K$, which results in the prominent hydrogen embrittlement. Thus, it is difficult for $5 \mathrm{~A}$ metals to attain high $J$ in spite of their high $\Phi$. The other methods to attain large $J$ are to make $\Delta P^{1 / 2}$ large and/or to make $L$ small. To satisfy such requirements, the high strength and the high resistance to the hydrogen embrittlement are

\footnotetext{
${ }^{* 1}$ Graduate student, Department of Materials Science, Kitami Institute of Technology. Present address: The Japan Steel Works, LTD, Chatsumachi 4, Muroran, Hokkaido 051-8505, Japan.

${ }^{* 2}$ Corresponding author, E-mail address: aokiky@mail.kitami-it.ac.jp
}

essential for the membrane. However, the coexistence of high $\Phi$ with high resistance to the hydrogen embrittlement is generally incompatible in single-phase alloys as mentioned above. So far, there has been no useful guideline for the suppression of the hydrogen embrittlement. Recently, the present authors have proposed new hydrogen permeation alloys on the basis of the concept of duplex phases. ${ }^{9,10)}$ An example of such alloys is the Nb-Ti-Ni system, and its phase diagram at $1173 \mathrm{~K}$ is shown in Fig. $1 .{ }^{11)} \mathrm{We}$ can see that a bcc-(Nb, Ti) solid solution coexists with a B2-TiNi compound over a wide range of compositions. $\mathrm{Nb}$ is ductile and shows the highest $\Phi$ among the 5A metals. ${ }^{4)}$ On the other hand, TiNi is ductile and shows interesting mechanical properties such as a shape memory effect and superelasticity. ${ }^{12)}$ Furthermore, TiNi absorbs hydrogen forming a solid solution and does not disintegrate spontaneously, although its $\Phi$ is low and $2.18 \times 10^{-9}\left[\mathrm{~mol} \mathrm{H}_{2} \mathrm{~m}^{-1} \mathrm{~s}^{-1}\right.$

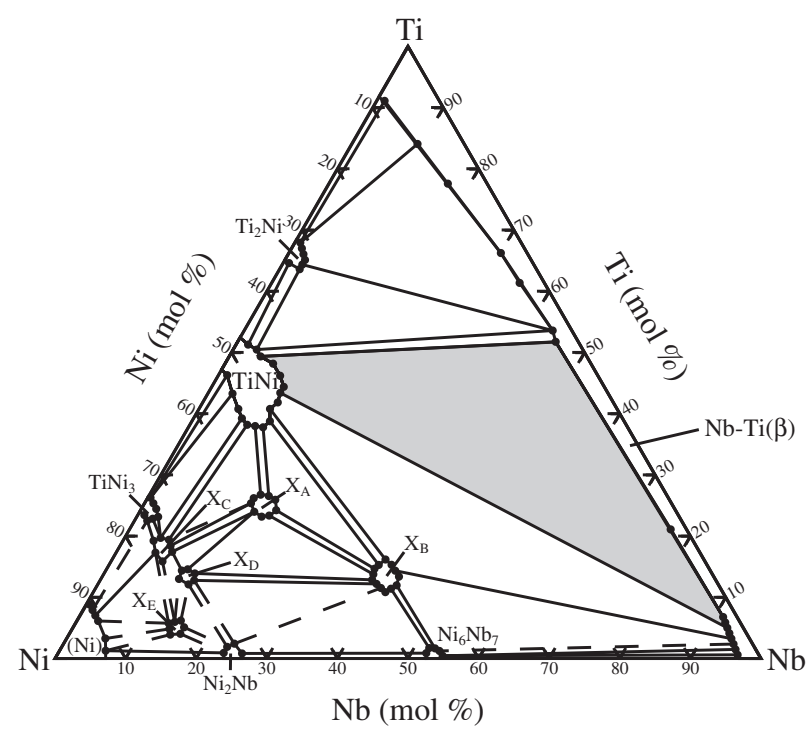

Fig. 1 The $1173 \mathrm{~K}$ isothermal section of the Nb-Ti-Ni ternary system. 
$\left.\mathrm{Pa}^{-0.5}\right]$ at $673 \mathrm{~K}^{13)}$ From these experimental results, it is interesting to investigate hydrogen permeability $\Phi$ of the $\mathrm{Nb}$ (TiNi) duplex phase alloys. This paper describes a study on the relation between microstructures and $\Phi$ in the as-cast NbTi-Ni alloys.

\section{Experimental}

About $20 \mathrm{~g}$ ingots of $\mathrm{Nb}_{x} \mathrm{Ti}_{y} \mathrm{Ni}_{(100-x-y)}$ alloys (mol\%) were prepared by arc melting using $\mathrm{Nb}$ ( 99.9 mass $\%$ purity), Ti ( 99.5 mass\% purity) and $\mathrm{Ni}$ ( 99.9 mass $\%$ purity) in a purified argon atmosphere. Disk samples of $12 \mathrm{~mm}$ in diameter and $0.55-0.75 \mathrm{~mm}$ in thickness were cut from the ductile alloy ingots, i.e., unbreakable alloys by hammering, using a spark erosion wire-cutting machine. Microstructural and structural examinations were carried out with a scanning electron microscope (SEM) and a powder X-ray diffractometer (XRD), respectively. Chemical compositions were determined using an energy dispersive X-ray spectrometer (EDS) attached to SEM. Both sides of the disks were polished with an abrasive paper, buff and $\alpha$-alumina of $0.5 \mu \mathrm{m}$ particle size, followed by coating with $\mathrm{Pd}$ of $190 \mathrm{~nm}$ in thickness using an RF magnetron-sputtering machine to avoid oxidation and to enhance the dissociation of hydrogen molecules to atoms. The disk was sealed with copper gaskets and introduced into the hydrogen permeation measuring apparatus, which has been described in the previous paper. ${ }^{9)}$ Both sides of the disk were first evacuated using a diffusion pump up to below $3 \times 10^{-3} \mathrm{~Pa}$, and then the disk was heated to $673 \mathrm{~K}$ and kept at this temperature. High purity hydrogen (99.99999 vol\% purity) of 0.1 and $0.2 \mathrm{MPa}$ was introduced into the downstream and the upstream sides, respectively, followed by hydrogen permeation experiments. The hydrogen pressure on the upstream side was raised from 0.2 to $0.97 \mathrm{MPa}$ and the temperature was stepped down from $673 \mathrm{~K}$ to $523 \mathrm{~K}$ at $50 \mathrm{~K}$ intervals. Hydrogen flux $J$ [mol $\mathrm{H}_{2} \mathrm{~m}^{-2} \mathrm{~s}^{-1}$ ] was measured using a mass flow meter. Hydrogen permeability, $\Phi$, was determined from the slope of the relation between $(J x L)$ and $\Delta P^{1 / 2}$.

\section{Results}

\subsection{Microstructures and ductility of the arc-melted Nb- Ti-Ni alloys}

Figure 2 shows compositions (mol\%) of the $\mathrm{Nb}-\mathrm{Ti}-\mathrm{Ni}$ alloys investigated in the present work. Chemical composition $(\mathrm{mol} \%)$ of the $(\mathrm{A})-(\mathrm{H})$ alloys and their constituting phases are tabulated in Table 1. Solid squares and circles denote brittle alloys in the as-cast state and hydrogen embrittled ones, respectively. Open circles and triangles denote the alloys for which the hydrogen permeation experiment is possible. The $\Phi$ values denoted by the open circles are of the order of $10^{-9}$ and $10^{-8}\left[\mathrm{~mol} \mathrm{H}_{2} \mathrm{~m}^{-1} \mathrm{~s}^{-1} \mathrm{~Pa}^{-0.5}\right]$, while that denoted by the open triangles are of the order of $10^{-9}\left[\mathrm{~mol} \mathrm{H}_{2} \mathrm{~m}^{-1} \mathrm{~s}^{-1} \mathrm{~Pa}^{-0.5}\right]$ or less. Alloys having 20 mole $\% \mathrm{Ti}$ are brittle in the as-cast state. As an example of such an alloy, Figure 3 shows a SEM photograph of the (A) alloy. Small white, dark and black regions are the $(\mathrm{Nb}, \mathrm{Ti})$ solid solution, the $\mathrm{Nb}_{8} \mathrm{Ti}_{3} \mathrm{Ni}_{9}$ compound and the TiNi compound, respectively. The (A) alloy is brittle in the as-

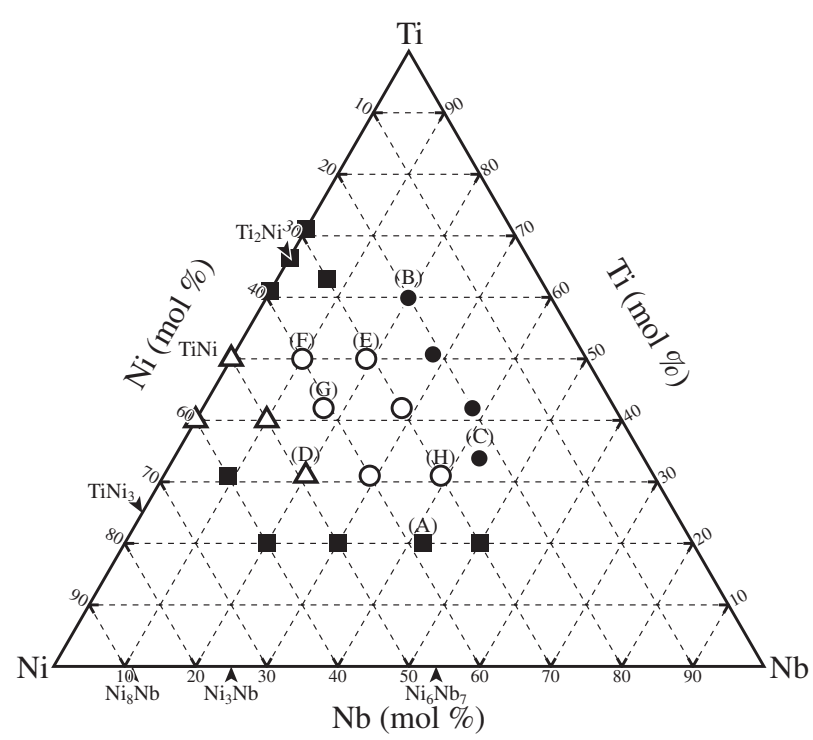

Fig. 2 Compositions ( $\mathrm{mol} \%$ ) of the alloys investigated in the present work. The solid squares and circles denote the brittle alloys in the as-cast state and the broken alloys by hydrogenation, respectively. On the other hand, the open triangles and circles indicate the alloys for which the hydrogen permeation experiments are possible.

cast state, because it consists mainly of the brittle $\mathrm{Nb}_{44} \mathrm{Ti}_{17} \mathrm{Ni}_{39}\left(\mathrm{Nb}_{8} \mathrm{Ti}_{3} \mathrm{Ni}_{9}\right)$ phase. Furthermore, brittleness also appears in the alloys near by the $\mathrm{Ti}_{2} \mathrm{Ni}$ compound, because it is brittle in the as-cast state.

Figures 4(a) and (b) show SEM photographs of the (B) and the $(\mathrm{C})$ alloys, which are broken by the hydrogen embrittlement. White and black regions in the photograph of the (B) alloy are the $(\mathrm{Nb}, \mathrm{Ti})$ solid solution and the $\mathrm{Ti}_{2} \mathrm{Ni}$ compound, respectively. Since both phases absorb much amount of hydrogen and becomes brittle, the hydrogen embrittlement occurs in the (B) alloy. The (C) alloy consists of the (Nb, Ti) solid solution, the TiNi compound and the eutectic $\{(\mathrm{Nb}, \mathrm{Ti})-$ TiNi\} phase.

Figure 5 shows a low magnification photograph of SEM for the (C) alloy broken by the hydrogen embrittlement at $673 \mathrm{~K}$. Cracks pass through both the (Nb, Ti) and the eutectic $\{(\mathrm{Nb}, \mathrm{Ti})-\mathrm{TiNi}\}$ phases randomly. In spite of containing the eutectic $\{(\mathrm{Nb}, \mathrm{Ti})-\mathrm{TiNi}\}$ phase, the $(\mathrm{C})$ alloy is broken by the hydrogen embrittlement. The reason of the brittleness is discussed later on.

Figure 6 shows a SEM photograph of the (D) alloy for which the hydrogen permeation experiment is possible. This alloy consists of much amount of the ductile TiNi compound and the brittle $\mathrm{Nb}_{8} \mathrm{Ti}_{3} \mathrm{Ni}_{9}$ compound.

Figure 7 shows a SEM photograph of the (E) alloy for which the hydrogen permeation experiment is possible. The (E) alloy consists of the $(\mathrm{Nb}, \mathrm{Ti})$ solid solution, the TiNi compound and the $\mathrm{Ti}_{2} \mathrm{Ni}$ compound.

Figures 8(a), (b) and (c) show SEM photographs of the (F), the $(\mathrm{G})$ and the $(\mathrm{H})$ alloys, respectively, for which the hydrogen permeation experiment is possible. The $(\mathrm{F})$ alloy consists of the primary TiNi compound, eutectic $\{(\mathrm{Nb}, \mathrm{Ti})+$ TiNi phase together with a small amount the $\mathrm{Ti}_{2} \mathrm{Ni}$ compound. The $(\mathrm{G})$ alloy consists of the eutectic $\{(\mathrm{Nb}$, $\mathrm{Ti})+\mathrm{TiNi}$ \} phase with fine structures. On the other hand, the 
Table 1 Chemical composition (mol\%) of the $(\mathrm{A})-(\mathrm{H})$ alloys along with their constituting phases and their compositions (mol\%) in the $\mathrm{Nb}-\mathrm{Ti}-\mathrm{Ni}$ system.

\begin{tabular}{|c|c|c|c|c|c|c|c|}
\hline \multirow[t]{2}{*}{ alloy } & \multicolumn{3}{|c|}{ alloy composition (mol\%) } & \multirow[t]{2}{*}{ phase } & \multicolumn{3}{|c|}{$\begin{array}{l}\text { chemical composition of the } \\
\text { constituting phases }(\operatorname{mol} \%)\end{array}$} \\
\hline & $\mathrm{Nb}$ & $\mathrm{Ti}$ & $\mathrm{Ni}$ & & $\mathrm{Nb}$ & $\mathrm{Ti}$ & $\mathrm{Ni}$ \\
\hline \multirow[t]{3}{*}{ A } & 42 & 20 & 38 & $(\mathrm{Nb}, \mathrm{Ti})$ & 90 & 5 & 5 \\
\hline & & & & TiNi & 23 & 32 & 45 \\
\hline & & & & $\mathrm{Nb}_{8} \mathrm{Ti}_{3} \mathrm{Ni}_{9}$ & 44 & 17 & 39 \\
\hline \multirow[t]{2}{*}{$\mathrm{B}$} & 20 & 60 & 20 & $(\mathrm{Nb}, \mathrm{Ti})$ & 40 & 56 & 4 \\
\hline & & & & $\mathrm{Ti}_{2} \mathrm{Ni}$ & 5 & 64 & 31 \\
\hline \multirow[t]{3}{*}{$\mathrm{C}$} & 43 & 34 & 23 & $(\mathrm{Nb}, \mathrm{Ti})$ & 80 & 17 & 3 \\
\hline & & & & $\mathrm{TiNi}$ & 5 & 48 & 47 \\
\hline & & & & $(\mathrm{Nb}, \mathrm{Ti})+\mathrm{TiNi}$ & 17 & 43 & 40 \\
\hline \multirow[t]{2}{*}{$\mathrm{D}$} & 20 & 31 & 49 & TiNi & 14 & 35 & 51 \\
\hline & & & & $\mathrm{Nb}_{8} \mathrm{Ti}_{3} \mathrm{Ni}_{9}$ & 36 & 18 & 46 \\
\hline \multirow[t]{2}{*}{$\mathrm{E}$} & 21 & 50 & 29 & $(\mathrm{Nb}, \mathrm{Ti})$ & 66 & 31 & 3 \\
\hline & & & & TiNi & 9 & 49 & 42 \\
\hline \multirow[t]{3}{*}{$\mathrm{F}$} & 10 & 50 & 40 & $\mathrm{Ti}_{2} \mathrm{Ni}$ & 7 & 35 & 58 \\
\hline & & & & TiNi & 3 & 48 & 49 \\
\hline & & & & $(\mathrm{Nb}, \mathrm{Ti})+\mathrm{TiNi}$ & 17 & 47 & 36 \\
\hline G & 17 & 42 & 41 & $(\mathrm{Nb}, \mathrm{Ti})+\mathrm{TiNi}$ & 17 & 42 & 41 \\
\hline \multirow[t]{2}{*}{$\mathrm{H}$} & 39 & 31 & 30 & $(\mathrm{Nb}, \mathrm{Ti})$ & 83 & 13 & 4 \\
\hline & & & & $(\mathrm{Nb}, \mathrm{Ti})+\mathrm{TiNi}$ & 21 & 38 & 41 \\
\hline
\end{tabular}

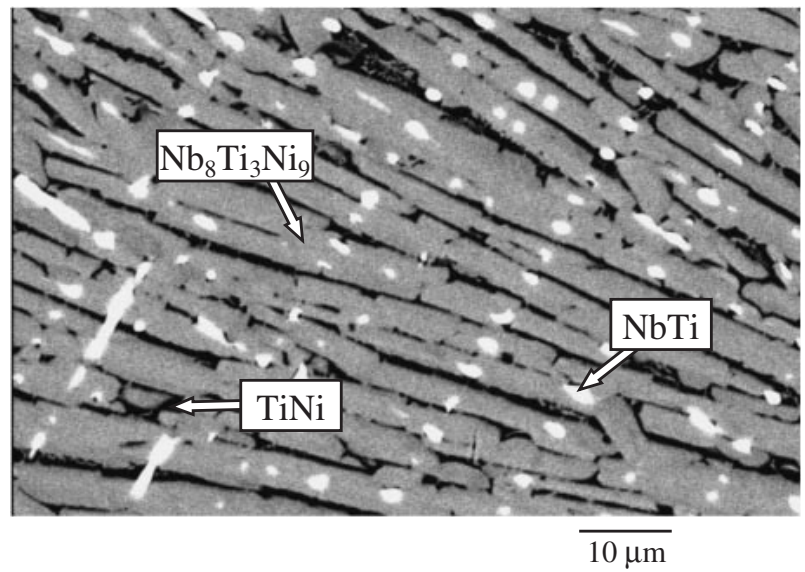

Fig. 3 A SEM photograph of the (A) $\mathrm{Nb}_{42} \mathrm{Ti}_{20} \mathrm{Ni}_{38}$ alloy that is brittle in the arc-melted state.

(H) alloy consists of the primary $(\mathrm{Nb}, \mathrm{Ti})$ solid solution and eutectic $\{(\mathrm{Nb}, \mathrm{Ti})+\mathrm{TiNi}\}$ phase. Thus, all of these alloys contain the eutectic phase.

Figure 9 shows the XRD pattern of the $(\mathrm{H})$ alloy consisting of the primary $(\mathrm{Nb}, \mathrm{Ti})$ solid solution and the eutectic $\{(\mathrm{Nb}$, $\mathrm{Ti})+\mathrm{TiNi}\}$ phase at room temperature. This pattern consists of two bcc phases, and their lattice parameters are calculated to be 0.303 and $0.330 \mathrm{~nm}$. They are close to that of B2-TiNi $(a=0.3026 \mathrm{~nm})$ and bcc- $(\mathrm{Nb}, \mathrm{Ti})$ alloy $\left.(a=0.3301 \mathrm{~nm}){ }^{12}\right)$ Then, the Bragg peaks in Fig. 9 may correspond to the B2TiNi $(a=0.303 \mathrm{~nm})$ and the bcc-(Nb, Ti) solid solution $(a=0.330 \mathrm{~nm})$.
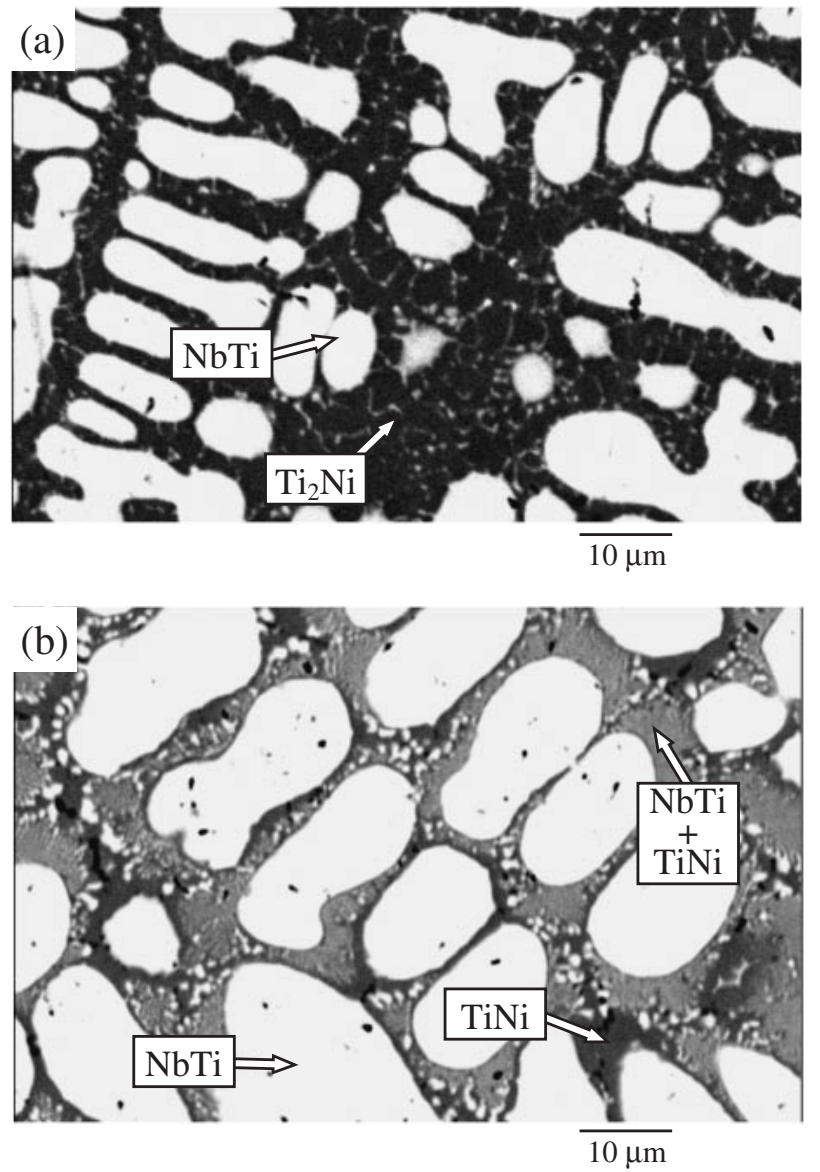

Fig. 4 (a) and (b) SEM photographs of the (B) $\mathrm{Nb}_{20} \mathrm{Ti}_{60} \mathrm{Ni}_{20}$ and (C) $\mathrm{Nb}_{43} \mathrm{Ti}_{34} \mathrm{Ni}_{23}$ alloys broken by the hydrogen embrittlement. 


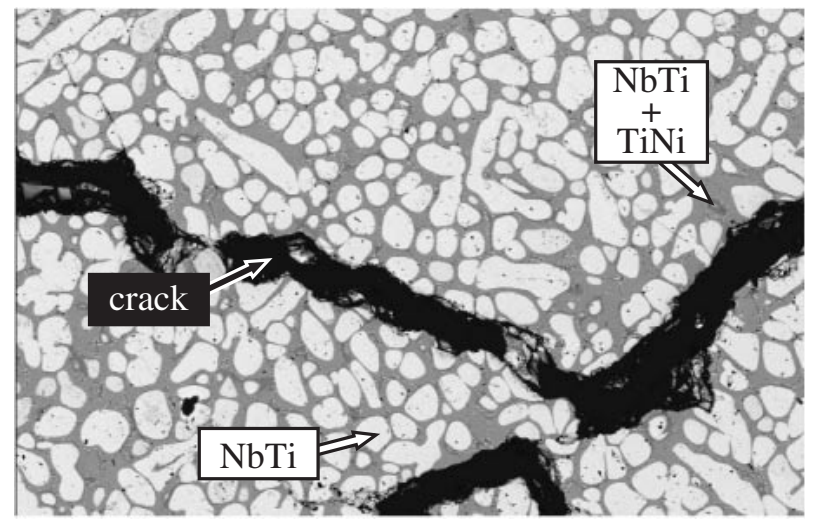

$100 \mu \mathrm{m}$

Fig. 5 A low magnification $\mathrm{SEM}$ photograph of the (C) $\mathrm{Nb}_{43} \mathrm{Ti}_{34} \mathrm{Ni}_{23}$ alloy broken during the hydrogen permeation experiment at $673 \mathrm{~K}$.

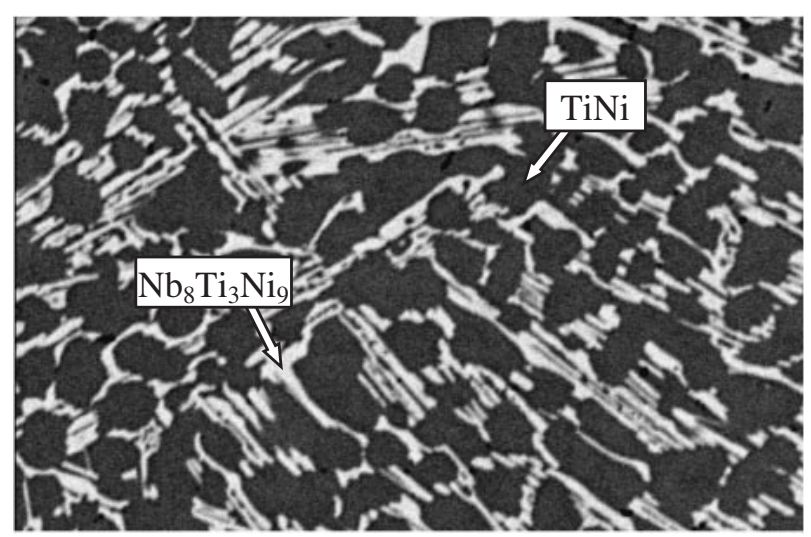

$\overline{10 \mu \mathrm{m}}$

Fig. 6 A SEM photograph of (D) $\mathrm{Nb}_{20} \mathrm{Ti}_{31} \mathrm{Ni}_{49}$ alloy for which the hydrogen permeation experiment is possible.

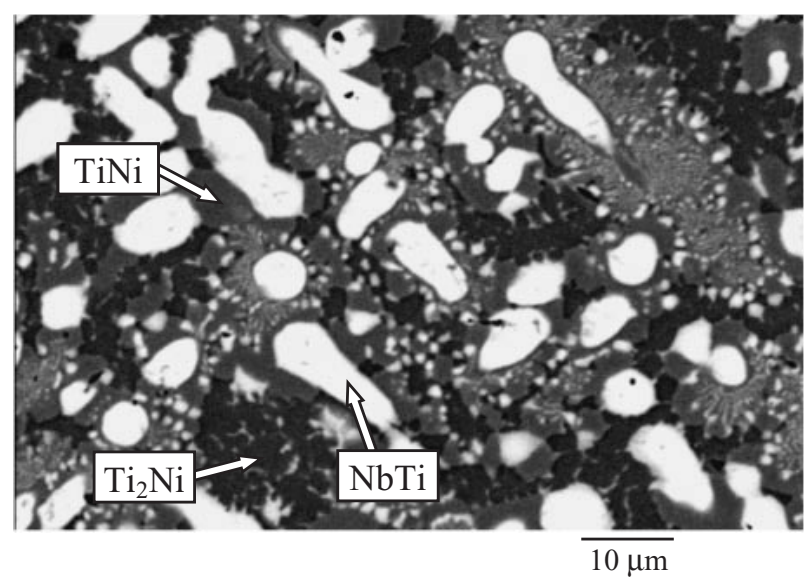

Fig. 7 A SEM photographs of the (E) $\mathrm{Nb}_{21} \mathrm{Ti}_{50} \mathrm{Ni}_{29}$ alloy for which the hydrogen permeation experiments are possible.

\subsection{Hydrogen permeability of the Nb-Ti-Ni alloys}

3.2.1 The $\mathrm{Nb}_{x} \mathrm{Ti}_{50-x} \mathrm{Ni}_{50}$ alloys $(x=0-20)$ and the $\mathrm{Ti}_{40} \mathrm{Ni}_{60}$ alloy

The $\Phi$ value of TiNi has been reported to be $2.18 \times 10^{-9}$ $\left[\mathrm{mol} \mathrm{H} \mathrm{m}^{-1} \mathrm{~s}^{-1} \mathrm{~Pa}^{-0.5}\right.$ ] at $673 \mathrm{~K}^{13)}$ The present work
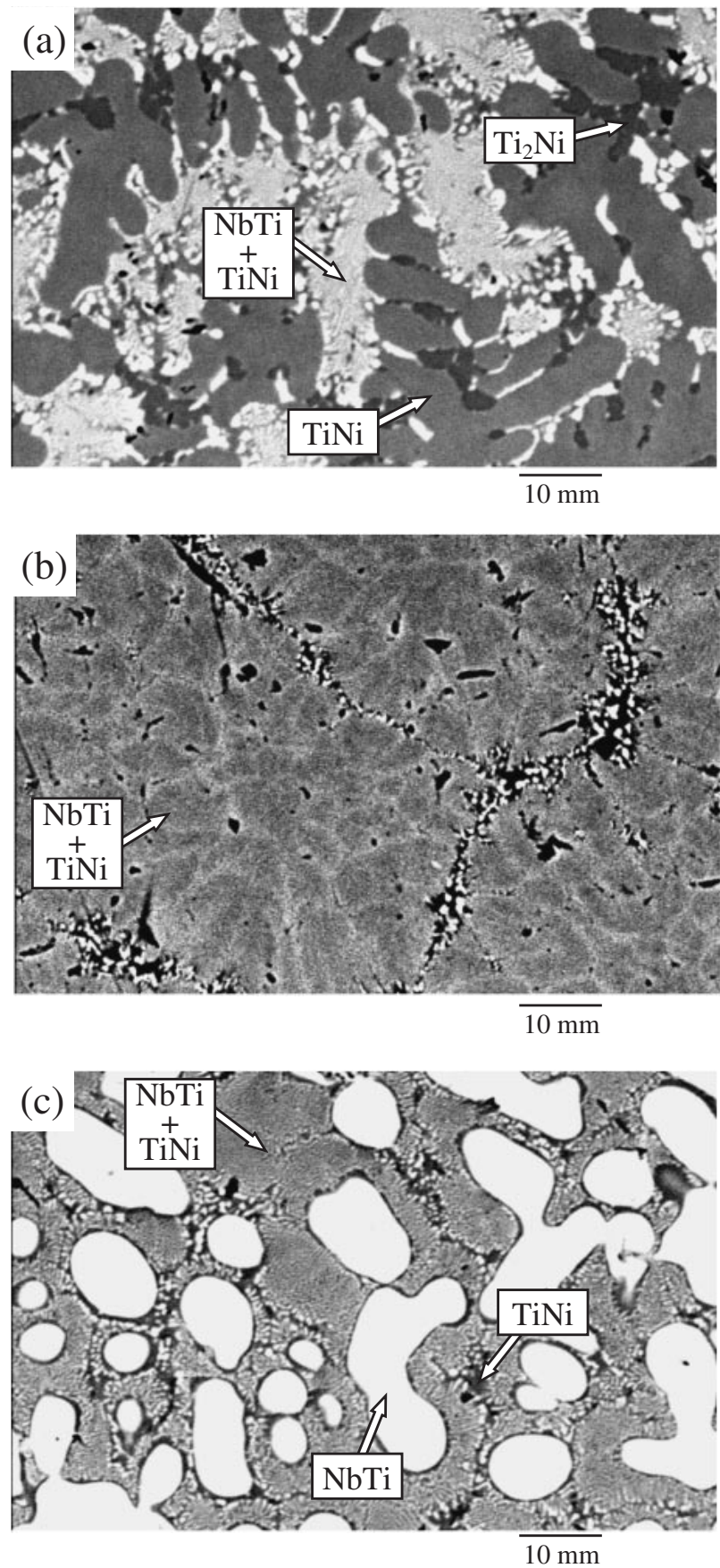

Fig. 8 (a), (b) and (c) SEM photographs of the (F) $\mathrm{Nb}_{10} \mathrm{Ti}_{50} \mathrm{Ni}_{40}$, the (G) $\mathrm{Nb}_{17} \mathrm{Ti}_{42} \mathrm{Ni}_{41}$ and the $(\mathrm{H}) \mathrm{Nb}_{39} \mathrm{Ti}_{31} \mathrm{Ni}_{30}$ alloys for which the hydrogen permeation experiments are possible.

indicates that the $\Phi$ values for the $\mathrm{Nb}_{x} \mathrm{Ti}_{50-x} \mathrm{Ni}_{50}$ alloys and the $\mathrm{Ti}_{40} \mathrm{Ni}_{60}$ one, which contain much amount of $\mathrm{TiNi}$, are lower that that of TiNi or immeasurable.

\subsubsection{The $\mathrm{Nb}_{x} \mathrm{Ti}_{60-x} \mathrm{Ni}_{40}$ alloys $(x=10-29 \mathrm{~mol} \%)$}

Figure 10 shows the plot of $\Phi$ for the $\mathrm{Nb}_{x} \mathrm{Ti}_{60-x} \mathrm{Ni}_{40}$ alloys in the form of the Arrhenius plot. For reference, the $\Phi$ values for Pd determined using the apparatus and the procedure adopted in the present work are also plotted in this figure, because their values vary widely depending on the researchers. $^{14)}$

The $\Phi$ value increases with increasing temperature and the amount of $\mathrm{Nb}$, but is lower than that of $\mathrm{Pd}$. That of the 


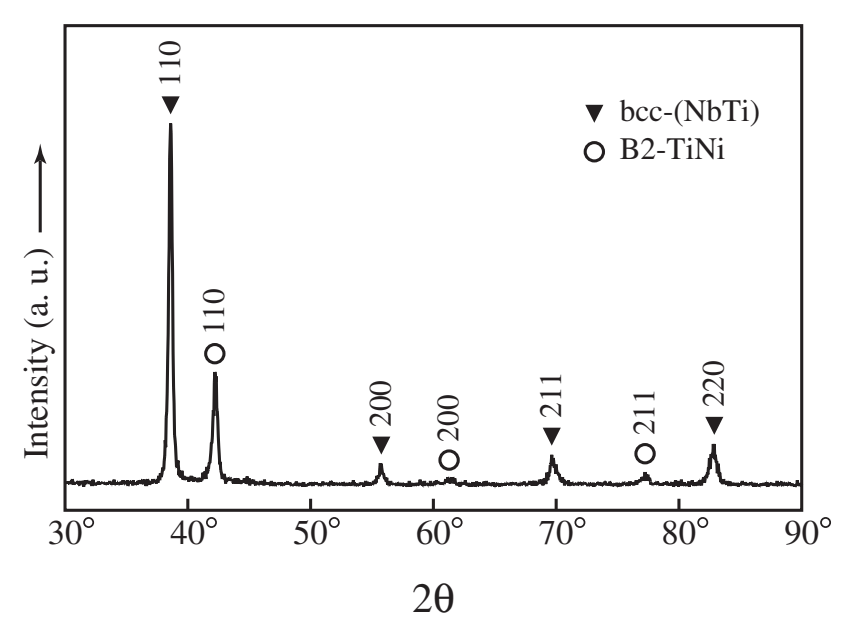

Fig. 9 The XRD pattern of the as-cast $\mathrm{Nb}_{39} \mathrm{Ti}_{31} \mathrm{Ni}_{30}$ alloy at room temperature.

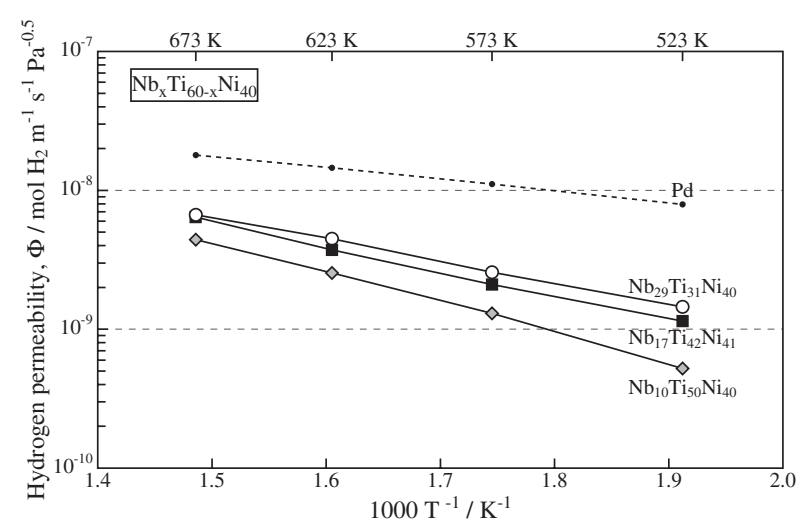

Fig. 10 The value of $\Phi$ for the $\mathrm{Nb}_{x} \mathrm{Ti}_{60-x} \mathrm{Ni}_{40}$ alloys in the form of the Arrhenius plot.

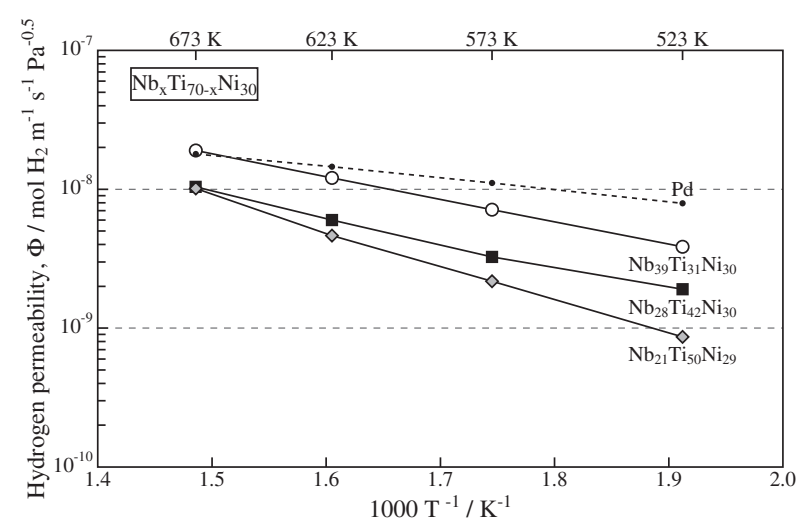

Fig. 11 The value of $\Phi$ for the $\mathrm{Nb}_{x} \mathrm{Ti}_{70-x} \mathrm{Ni}_{30}$ alloys in the form of the Arrhenius plot.

eutectic (G) alloy is $6.42 \times 10^{-9}\left[\mathrm{~mol} \mathrm{H}_{2} \mathrm{~m}^{-1} \mathrm{~s}^{-1} \mathrm{~Pa}^{-0.5}\right]$ at $673 \mathrm{~K}$. On the other hand, the $\Phi$ value of the $(\mathrm{F})$ alloy, consisting of the primary B2-TiNi phase and the eutectic phase, is $4.52 \times 10^{-9}\left[\mathrm{~mol} \mathrm{H} \mathrm{H}^{-1} \mathrm{~s}^{-1} \mathrm{~Pa}^{-0.5}\right]$ at $673 \mathrm{~K}$, which is the lowest one in the alloys shown in Figs. 10 and 11 .

\subsubsection{The $\mathrm{Nb}_{x} \mathrm{Ti}_{70-x} \mathrm{Ni}_{30}$ alloys ( $\left.x=21-39 \mathrm{~mol} \%\right)$}

Figure 11 shows the plot of the $\Phi$ value for the $\mathrm{Nb}_{x} \mathrm{Ti}_{70-x} \mathrm{Ni}_{30}$ alloys and $\mathrm{Pd}$ in the form of the Arrhenius plot. The $\Phi$ value for the (H) alloy, consisting of the primary bcc- $(\mathrm{Nb}, \mathrm{Ti})$ phase and the eutectic phase, is $1.93 \times 10^{-8}$ [mol H $\mathrm{m}^{-1} \mathrm{~s}^{-1} \mathrm{~Pa}^{-0.5}$ ] at $673 \mathrm{~K}$, which is the highest in the $\mathrm{Nb}-\mathrm{Ti}-\mathrm{Ni}$ system investigated in the present work and is comparable to that of $\mathrm{Pd}$.

\section{Discussion}

\subsection{Microstructures of hydrogen permeable alloys}

The hydrogen permeable alloys investigated in the Nb-Ti$\mathrm{Ni}$ system are divided into two groups from the point of microstructures, i.e., alloys containing much amount of the eutectic phase $\{$ the $(\mathrm{F})$, the $(\mathrm{G})$, and the $(\mathrm{H})$ alloys $\}$ and ones without it $\{$ the $(\mathrm{D})$ and the $(\mathrm{E})$ alloy $\}$. The $(\mathrm{G})$ alloy consists of eutectic $\{(\mathrm{Nb}, \mathrm{Ti})+\mathrm{TiNi}\}$ phase, and shows the highest resistance to the hydrogen embrittlement. The $(\mathrm{H})$ alloy, consisting of the primary bcc- $(\mathrm{Nb}, \mathrm{Ti})$ phase and the eutectic $\{(\mathrm{Nb}, \mathrm{Ti})+\mathrm{TiNi}\}$ phase, shows the highest $\Phi$ value in the alloys investigated in the present work. On the contrary, the (F) alloy consisting of the primary B2-TiNi phase and the eutectic $\{(\mathrm{Nb}, \mathrm{Ti})+\mathrm{TiNi}\}$ phase shows the lowest $\Phi$ value in the alloys shown in Figs. 10 and 11. All of these alloys contain much amount of the eutectic phase that suppresses the hydrogen embrittlement. In spite of that the $(\mathrm{C})$ alloy also consists of the primary bcc-( $\mathrm{Nb}, \mathrm{Ti})$ phase and the eutectic $\{(\mathrm{Nb}, \mathrm{Ti})+\mathrm{TiNi}\}$ phase, it is broken by the hydrogen embrittlement in contrast to the $(\mathrm{H})$ alloy. The volume fraction of the eutectic $\{(\mathrm{Nb}, \mathrm{Ti})+\mathrm{TiNi}\}$ phase in the $(\mathrm{H})$ and the (C) alloy is $60 \%$ and $45 \%$, respectively. Consequently, it is suggested that the hydrogen embrittlement occurs when the volume fraction of the eutectic $\{(\mathrm{Nb}, \mathrm{Ti})+\mathrm{TiNi}\}$ phase is lower than the critical value, about $50 \%$.

\subsection{Estimation of $\Phi$ in the primary phases and the factors controlling hydrogen permeability of duplex phase alloys}

The volume fraction of the primary B2-TiNi phase and the eutectic $\{(\mathrm{Nb}, \mathrm{Ti})+(\mathrm{TiNi})\}$ phase in the $(\mathrm{F})$ alloy is $45 \%$ and $55 \%$, respectively. Furthermore, the $\Phi$ values of this alloy and the eutectic $(\mathrm{G})$ phase are $4.52 \times 10^{-9}$ and $6.42 \times 10^{-9}$ [mol H $\left.\mathrm{m}^{-1} \mathrm{~s}^{-1} \mathrm{~Pa}^{-0.5}\right]$ at $673 \mathrm{~K}$, respectively. If it is assumed that $\Phi$ of the duplex phase alloy is proportional to the volume fraction of the constituting phases, that for the primary TiNi based phase, $\mathrm{Nb}_{3} \mathrm{Ti}_{48} \mathrm{Ni}_{49}$, is estimated to be $2.3 \times 10^{-9}\left[\mathrm{~mol} \mathrm{H}_{2} \mathrm{~m}^{-1} \mathrm{~s}^{-1} \mathrm{~Pa}^{-0.5}\right]$, which is in good agreement with that of binary TiNi $=2.18 \times 10^{-9}\left[\mathrm{~mol} \mathrm{H}_{2}\right.$ $\left.\mathrm{m}^{-1} \mathrm{~s}^{-1} \mathrm{~Pa}^{-0.5}\right] .{ }^{13)}$ Then, it is reasonable to consider that the $\Phi$ value for the duplex phase alloy is proportional to the volume fraction of the constituting phases. On the other hand, the volume fraction of the primary $(\mathrm{Nb}, \mathrm{Ti})$ phase and the eutectic $\{(\mathrm{Nb}, \mathrm{Ti})+(\mathrm{TiNi})\}$ phase in the $(\mathrm{H})$ alloy is about $40 \%$ and $60 \%$, respectively, as mentioned above. Furthermore, the $\Phi$ values of this alloy and the eutectic phase $(\mathrm{G})$ in the $(\mathrm{H})$ alloy is $1.93 \times 10^{-8}$ and $6.42 \times 10^{-9}\left[\mathrm{~mol} \mathrm{H}_{2} \mathrm{~m}^{-1}\right.$ $\mathrm{s}^{-1} \mathrm{~Pa}^{-0.5}$, respectively. Then, the $\Phi$ value for the primary ( Ti, Nb) phase, $\mathrm{Nb}_{83} \mathrm{Ti}_{13} \mathrm{Ni}_{4}$, is estimated to be $3.23 \times 10^{-8}$ $\left[\mathrm{mol} \mathrm{H} \mathrm{m}^{-1} \mathrm{~s}^{-1} \mathrm{~Pa}^{-0.5}\right]$. Since the $\Phi$ value for the primary 
$(\mathrm{Nb}, \mathrm{Ti})$ phase is 5 times larger than that of the eutectic phase, hydrogen permeation through the $(\mathrm{H})$ alloy is determined by the primary $(\mathrm{Nb}, \mathrm{Ti})$ phase. The single-phase primary alloy of $(\mathrm{Nb}, \mathrm{Ti})$, i.e., $\mathrm{Nb}_{83} \mathrm{Ti}_{13} \mathrm{Ni}_{4}$, becomes brittle and is broken down by hydrogenation, but it in the $(\mathrm{H})$ alloy keeps the original shape. Consequently, the eutectic structure $\{(\mathrm{Nb}$, $\mathrm{Ti})+\mathrm{TiNi}\}$ is considered to suppress the volume expansion of $(\mathrm{Nb}, \mathrm{Ti})$, resulting in the prevention of the hydrogen embrittlement of the $(\mathrm{Nb}, \mathrm{Ti})$ phase. We conclude from the above experimental results that the primary $(\mathrm{Nb}, \mathrm{Ti})$ phase plays a major role in the hydrogen permeation, while its hydrogen embrittlement is reduced in the presence of the fine eutectic structure $\{(\mathrm{Nb}, \mathrm{Ti})+\mathrm{TiNi}\}$.

\section{Summary and Conclusion}

Microstructures, ductility and hydrogen permeability $(\Phi)$ in the as-cast $\mathrm{Nb}$-Ti-Ni alloys has been investigated by SEM, by hammering and by the gas permeation technique. These alloys are divided into three groups, i.e., brittle alloys in the as-cast state, hydrogen embrittled ones and hydrogen permeable ones depending on their chemical compositions and microstructures. The $\Phi$ value increases with increasing temperature and the amount of the $\mathrm{Nb}$ content. The $\mathrm{Nb}_{39} \mathrm{Ti}_{31} \mathrm{Ni}_{30}$ alloy consisting of the primary bcc-(Nb, Ti) phase and the eutectic $\{(\mathrm{Nb}, \mathrm{Ti})+\mathrm{TiNi}\}$ one shows the highest $\Phi=1.93 \times 10^{-8}\left[\mathrm{~mol} \mathrm{H}_{2} \mathrm{~m}^{-1} \mathrm{~s}^{-1} \mathrm{~Pa}^{-0.5}\right]$ at $673 \mathrm{~K}$, which is equivalent to that of $\mathrm{Pd}$. On the other hand, the $\mathrm{Nb}_{10} \mathrm{Ti}_{50} \mathrm{Ni}_{40}$ alloy consisting of the primary B2-TiNi phase and the eutectic $\{(\mathrm{Nb}, \mathrm{Ti})+\mathrm{TiNi}\}$ one show the lowest $\Phi=$ $4.52 \times 10^{-9}\left[\mathrm{~mol} \mathrm{H} 2 \mathrm{~m}^{-1} \mathrm{~s}^{-1} \mathrm{~Pa}^{-0.5}\right.$ ] among the alloys for which $\Phi$ is measurable at $673 \mathrm{~K}$. The eutectic phase suppresses the hydrogen embrittlement, while the primary bcc- $(\mathrm{Nb}, \mathrm{Ti})$ phase contributes to the hydrogen permeation. The present work clearly demonstrates that composite alloys containing eutectic microstructures are promising for new hydrogen permeation alloy membranes with the high resistance to the hydrogen embrittlement.

\section{Acknowledgements}

This work has been supported in part by a Grant-in-Aid for Scientific Research (B) of Japan Society for the Promotion of Science (JSPS), and by Industrial Technology Research Grant Program in '04 from New Energy and Industrial Technology Department Organization (NEDO) of Japan.

\section{REFERENCES}

1) E. Kikuchi: Catalysis Today 56 (2000) 97-101.

2) V. Z. Mordkovich, Y. K. Baichtock and M. H. Sosna: Platinum Metals Rev. 36 (1992) 90-97.

3) C. Nishimura, M. Komaki and M. Amano: Mater. Trans. JIM 32 (1991) 501-507.

4) R. E. Buxbaum and A. B. Kinney: Ind. Eng. Chem. Res. 35 (1995) 530537.

5) C. Nishimura, M. Komaki, S. Hwang and M. Amano: J. Alloys and Comp. 330-332 (2002) 902-906.

6) Y. Zhang, T. Ozaki, M. Komaki and C. Nishimura: Scr. Mater. 47 (2002) 601-606.

7) T. Ozaki, Y. Zhang, M. Komaki and C. Nishimura: Int. J. Hydrogen Energy 28 (2003) 1229-1235.

8) Y. Zhang, T. Ozaki, M. Komaki and C. Nishimura: J. Membrane Sci. 224 (2003) 81-91.

9) K. Hashi, K. Ishikawa, T. Matsuda and K. Aoki: J. Alloys and Comp. 368 (2004) 215-220.

10) T. Takano, K. Ishikawa, T. Matsuda and K. Aoki: Mater. Trans. 45 (2004) 3360-3362.

11) Y. Guanjun and H. Shiming: J. Alloys and Comp. 297 (2000) 226-230.

12) M. Piao, S. Miyazaki, K. Otsuka and N. Nishida: Mater. Trans. JIM 33 (1992) 337-345.

13) R. Schmidt, M. Schlereth, H. Wipf, W. Assmus and M. Müllner: J. Phys. Condens Matter 1 (1989) 2473-2482.

14) B. D. Morreale, M. V. Ciocco, R. M. Enik, B. I. Morsi, B. H. Howard, A. V. Cugini and K. S. Rothenberger: J. Membrane Sci. 212 (2003) 8797. 